\title{
Analisa Postur Kerja Menggunakan Metode OWAS dan RULA
}

\author{
Alfin Nur Bintang*, Shanty Kusuma Dewi \\ Jurusan Teknik Industri, Fakultas Teknik, Universitas Muhammadiyah Malang \\ Jl. Raya Tlogomas 246 Malang 65144 Jawa Timur \\ *Surel: alfin@gmail.com
}

\begin{abstract}
Material handling activities of sugar in PG Tjoekir storage warehouse is done manually. Continuous material handling activity can cause musculoskeletal disorders to workers. The distribution of questionnaires Nordic Body Map known some complaints experienced by workers in the process of material handling sugar. The OWAS and RULA methods are methods for evaluating and analyzing worker attitudes that can cause musculoskeletal disorders. Some activities in the storage warehouse PG Tjoekir is ranging from lifting, moving and putting sugar. OWAS method calculation results obtained risk level score 3. Risk level risk of RULA method 4. The calculation results show some worker posture causing musculoskeletal risk so that need improvement. Proposed repair work posture is to design two-wheeled hand truck. Hand trucks help reduce the risk of musculoskeletal injuries for workers.
\end{abstract}

Keywords: Musculoskeletal disorders, Nordic Body Map, OWAS, RULA

\begin{abstract}
Abstrak
Aktivitas pengangkutan gula pada gudang penyimpanan PG Tjoekir dilakukan pekerja secara manual. Kegiatan pengangkutan dilakukan secara terus-menerus dapat menyebabkan risiko musculoskeletal disorders pada pekerja. Penyebaran kuesioner Nordic Body Map diketahui beberapa keluhan yang dialami pekerja dalam proses pengangkutan gula. Metode OWAS dan RULA merupakan metode untuk mengevaluasi dan menganalisis sikap pekerja yang dapat menyebabkan cedera musculoskeletal disorders. Beberapa aktivitas pada gudang penyimpanan PG Tjoekir yaitu mulai dari pengangkatan, pemindahan dan peletakan gula. Hasil perhitungan metode OWAS diperoleh skor level risiko 3. Skor level risiko metode RULA sebesar 4. Hasil perhitungan menunjukkan beberapa postur tubuh pekerja menyebabkan risiko musculoskeletal sehingga perlu dilakukan perbaikan. Usulan perbaikan postur kerja adalah dengan mendesain hand truck dua roda. Hand truck membantu mengurangi risiko cedera musculoskeletal bagi pekerja.
\end{abstract}

Kata kunci: Musculoskeletal disorders, Nordic Body Map, OWAS, RULA

\section{Pendahuluan}

Ergonomi didefinisikan sebagai studi tentang aspek manusia dalam lingkungan kerjanya yang ditinjau secara anatomi, fisiologi, psikologi, engineering, manajemen dan perancangan dan desain. Ergonomi berkenaan pula dengan optimasi, efisiensi, kesehatan, keselamatan dan kenyamanan manusia di tempat kerja, di rumah, dan tempat rekreasi [1]. Musculoskeletal Disorders merupakan salah satu cedera yang sering dialami pekerja dalam melakukan kegiatan Manual Material Handling (MMH) yaitu cedera pada otot, urat syaraf, urat daging, tulang, persendian tulang, tulang rawan yang disebabkan oleh aktivitas kerja. Ketika seseorang bekerja pada posisi berdiri atau duduk, pergerakan bagian tulang belakang, terutama bagian pinggang yang rentan dengan gerakan ekstrem yang dapat menyebabkan cedera [2].

Susihono [3] menjelaskan bahwa postur tubuh merupakan titik penentu dalam menganalisis keefektifan dari suatu pekerjaan. Apabila postur tubuh dalam bekerja 
sudah baik dan ergonomis maka dapat dipastikan hasil yang diperoleh oleh pekerja akan baik pula, akan tetapi bila postur kerja operator tersebut salah atau tidak ergonomis maka pekerja akan mudah kelelahan dan dapat terjadi kelainan pada bentuk tulang. Jika hal tersebut terjadi, hasil pekerjaan yang dilakukan juga akan mengalami penurunan dan tidak sesuai dengan yang diharapkan.

Pabrik Gula Tjoekir Jombang merupakan perusahaan yang bergerak dibidang industri yang memproduksi gula Superieure Hoofd Suiker (SHS). Selain itu, terdapat juga hasil produk sampingan yaitu tetes tebu dan pupuk kompos. Namun yang menjadi perhatian adalah pada bagian pemindahan gula ke gudang penyimpanan yang masih dilakukan secara manual. Tenaga kerja yang bekerja pada gudang sebanyak 41 orang. Tenaga kerja dibagi untuk menyelesaikan 2 tugas (pengangkutan produk jadi ke gudang penyimpanan dan pengangkutan produk jadi dari gudang penyimpanan ke truk petani).

Menurut Pamula [4], Ovako Work Posture Analysis System (OWAS) merupakan metode analisis sikap kerja yang mendefinisikan pergerakan bagian tubuh punggung, lengan, kaki dan berat beban yang diangkat. Masing-masing anggota tubuh tersebut diklasifikasikan menjadi sikap kerja. Sikap bagian tubuh yang diamati adalah punggung, lengan, kaki dan berat beban pekerja. Triyanto [5] menjelaskan bahwa Rapid Upper Limb Assessment (RULA) merupakan metode yang dikembangkan dalam bidang ergonomi yang menginvestasikan dan menilai posisi kerja yang dilakukan oleh tubuh bagian atas. Peralatan ini tidak melakukan peranti khusus dalam memberikan pengukuran postur leher, punggung dan tubuh bagian atas sejalan dengan fungsi otot dan beban eksternal yang ditopang oleh tubuh. Untuk menghasilkan suatu metode yang cepat digunakan, tubuh dibagi menjadi dua bagian, yaitu grup A dan grup B. Grup A meliputi lengan atas dan lengan bawah serta pergelangan tangan. Sementara grup B meliputi leher, punggung dan kaki. Beberapa penelitian tentang OWAS dilakukan oleh Mattila, et al. [6], Sari [7], dan Suwanto, et al. [8]. Hasil penelitian menunjukan metode OWAS efektif digunakan menilai mengevaluasi dan menganalisis sikap kerja sehingga diperoleh kategori dan rekomendasi metode kerja. Beberapa penelitian tentang RULA dilakukan oleh Dzikrillah and Yuliani [9], dan Susihono and Rubiati [10]. Hasil penelitian tersebut menunjukkan RULA dapat menilai postur kerja yang berisiko dan melakukan perbaikan segera.

Dari observasi dan pembagian kuesioner Nordic Body Map (NBM) kepada para pekerja, diketahui terdapat keluhan di antaranya sakit pada bahu, punggung, pinggang, lutut, kaki, betis, lengan dan leher. Keluhan disebabkan pekerja harus mengangkat gula dalam sehari sekitar 200-400sak gula dengan berat $50 \mathrm{~kg} / \mathrm{sak}$. Jika aktivitas tersebut dilakukan secara terus-menerus dapat mengakibatkan gangguan Musculoskeletal Disorders pada pekerja. Maka perlu dilakukan analisa sehingga risiko cedera dapat diminimalkan. Metode yang digunakan adalah Metode OWAS dan RULA. Metode OWAS dan RULA digunakan menganalisis sikap kerja pekerja. Metode OWAS dan RULA digunakan karena pekerja banyak menggunakan tubuh bagian atas saat beraktivitas. Penelitian sebelumnya umumnya hanya menghitung postur kerja dengan metode OWAS dan RULA. Sedangkan pada penelitian ini hasil akhirnya akan memberikan usulan perancangan alat bantu kerja yang ergonomis untuk mengurangi risiko gangguan Musculoskeletal Disorders pada pekerja .

\section{Metode Penelitian}

Tahapan penilaian postur kerja diawali dengan menyebarkan kuesioner Nordic Body Map (NBM). Priyono [11] menyatakan bahwa kuesioner NBM merupakan satu bentuk check list ergonomic yang digunakan karena sudah terstandardisasi dan tersusun rapi. NBM berfungsi mengetahui bagian tubuh manusia yang terasa sakit 
yang telah dibagi menjadi 9 bagian utama, yaitu leher, bahu, punggung bagian atas, siku, punggung bagian bawah, pergelangan tangan, pinggang/ pantat, lutut, tumit/ kaki.

Tahapan selanjutnya adalah menganalisis dan menilai postur kerja guna mengetahui bentuk postur tubuh pekerja saat melakukan aktivitas tersebut dengan metode OWAS dan RULA. Klasifikasi OWAS antara lain [12]:

a) Sikap Punggung : lurus, membungkuk, memutar atau miring ke samping, membungkuk dan memutar atau membungkuk ke depan dan menyamping.

b) Sikap Lengan : kedua lengan berada dibawah bahu, satu lengan berada pada atau diatas bahu, kedua lengan pada atau diatas bahu.

c) Sikap Kaki : duduk, berdiri bertumpu pada kedua kaki lurus, berdiri bertumpu pada satu kaki lurus, berdiri bertumpu pada kedua kaki dengan lutut ditekuk, berdiri bertumpu pada satu kaki dengan lutut ditekuk, berlutut pada satu atau kedua lutut, berjalan.

d) Berat Beban : kurang dari $10 \mathrm{Kg}(\mathrm{W}=10 \mathrm{Kg}), 10 \mathrm{Kg}-20 \mathrm{Kg}(10 \mathrm{Kg}<\mathrm{W} \leq 20 \mathrm{Kg})$, berat beban adalah lebih besar dari $20 \mathrm{Kg}(\mathrm{W}>20 \mathrm{Kg})$

Analisa postur kerja OWAS terdiri dari empat level skala sikap kerja yang berbahaya bagi para pekerja antara lain[12];

1. Kategori 1 : Pada sikap ini tidak ada masalah pada sistem musculoskeletal, tidak perlu ada perbaikan.

2. Kategori 2 : Pada sikap ini berbahaya pada sistem musculoskeletal, postur kerja mengakibatkan pengaruh ketegangan yang signifikan. Perlu perbaikan dimasa yang akan datang.

3. Kategori 3 : Pada sikap ini berbahaya pada sistem musculoskeletal, postur kerja mengakibatkan pengaruh ketegangan yang sangat signifikan. Perlu perbaikan segera mungkin.

4. Kategori 4 : Pada sikap ini sangat berbahaya pada sistem musculoskeletal, postur kerja ini mengakibatkan risiko yang jelas. Perlu perbaikan secara langsung atau saat ini juga.

Tahapan analisa RULA adalah [13];

a) Penilaian Skor Grup A :Postur tubuh grup A terdiri atas lengan atas (upper arm), lengan bawah (lower arm), pergelangan tangan (Wrist) dan putaran pergelangan tangan (wrist twist)

b) Penilaian Skor Grup B : Postur tubuh grup B terdiri atas leher (neck), batang tubuh (trunk), dan kaki (legs).

c) Skor Beban dan Aktivitas

d) Grand Score RULA

e) Interpretasi grand score : Grand score menunjukkan kebutuhan analisis kerja yang lebih mendalam dan menyediakan metode untuk memprioritaskan pekerjaan yang perlu dianalisis lebih lanjut.

Hasil scoring dengan menggunakan metode OWAS dan RULA dapat mengetahui postur yang menyebabkan cedera musculoskeletal disorders. Untuk mengurangi risiko cedera ini, dibuatlah usulan perbaikan berupa desain alat bantu kerja yang ergonomis. Desain alat bantu yang ergonomis didasarkan antropometri tubuh pekerja [14]. Alat bantu diharapkan dapat membantu meringankan beban pekerja.

\section{Hasil dan Pembahasan}

Untuk mengetahui keluhan pekerja saat aktivitas pemindahan karung gula terjadi, dilakukan penyebaran kuesioner Nordic Body Map kepada para pekerja. Data kuesioner Nordic Body Map aktivitas pemindahan karung gula pada Gudang Penyimpanan PG. Tjoekir ditunjukkan pada Tabel 1. 
Hasil rekapitulasi kuesioner Nordic Body Map menunjukkan keluhan yang dialami pekerja adalah sakit pada bagian leher, bahu, lengan, punggung, tangan dan kaki. Keluhan-keluhan pekerja inilah dapat menyebabkan cedera musculoskeletal, selain itu postur tubuh saat bekerja pun juga dapat menyebabkan cedera pada pekerja. Sehingga perlu dilakukan analisa postur tubuh pekerja saat melakukan aktivitas. Penilaian postur kerja dilakukan untuk mengetahui seberapa besar tingkat risiko cedera musculoskeletal pada pekerja. Postur tubuh pekerja yang diamati adalah mengangkat, memindah dan meletakan gula.

\subsection{Pengangkatan Karung Gula}

Pada aktivitas ini, pekerja mengangkat karung gula yang berada di lori ke punggung pekerja. Karung gula dipindahkan ke tempat yang disediakan. Gambaran postur tubuh pekerja saat mengangkat karung gula :

a) Pekerja 1

Hasil penilaian skor level aktivitas pengangkatan karung gula pada Gambar 1, ditunjukkan pada Tabel 2. Hasil penilaian aktivitas menggunakan metode OWAS dan RULA diperoleh bahwa aktivitas yang dilakukan dapat menyebabkan cedera musculoskeletal sehingga diperlukan adanya perbaikan segera untuk mengurangi risiko terjadinya cedera.

Tabel 1 Rekapitulasi kuesioner Nordic body map

\begin{tabular}{clcc}
\hline \multirow{2}{*}{ No } & \multicolumn{1}{c}{ Jenis Keluhan } & \multicolumn{2}{c}{ Sesudah bekerja } \\
\cline { 3 - 4 } 1 & Sakit kaku pada bagian leher atas & 22 & 19 \\
2 & Sakit kaku pada bagian leher bawah & 23 & 18 \\
3 & Sakit di bahu kiri & 10 & 31 \\
4 & Sakit di bahu kanan & 23 & 18 \\
5 & Sakit lengan atas kiri & 19 & 22 \\
6 & Sakit di punggung & 32 & 9 \\
7 & Sakit lengan atas kanan & 24 & 17 \\
8 & Sakit pada pinggang & 22 & 19 \\
9 & Sakit pada pinggul & 22 & 19 \\
10 & Sakit pada pantat & 7 & 34 \\
11 & Sakit pada siku kiri & 10 & 31 \\
12 & Sakit pada siku kanan & 20 & 21 \\
13 & Sakit lengan bawah kiri & 17 & 24 \\
14 & Sakit lengan bawah kanan & 28 & 13 \\
15 & Sakit pada pergelangan tangan kiri & 15 & 26 \\
16 & Sakit pada pergelangan tangan kanan & 15 & 26 \\
17 & Sakit pada tangan kiri & 17 & 24 \\
18 & Sakit pada tangan kanan & 24 & 17 \\
19 & Sakit pada paha kiri & 17 & 24 \\
20 & Sakit pada paha kanan & 17 & 24 \\
21 & Sakit pada lutut kiri & 27 & 14 \\
22 & Sakit pada lutut kanan & 27 & 14 \\
23 & Sakit pada betis kiri & 23 & 18 \\
24 & Sakit pada betis kanan & 22 & 19 \\
25 & Sakit pada pergelangan kaki kiri & 15 & 26 \\
26 & Sakit pada pergelangan kaki kanan & 22 & 19 \\
27 & Sakit pada kaki kiri & 25 & 16 \\
28 & Sakit pada kaki kanan & 25 & 16 \\
\hline
\end{tabular}




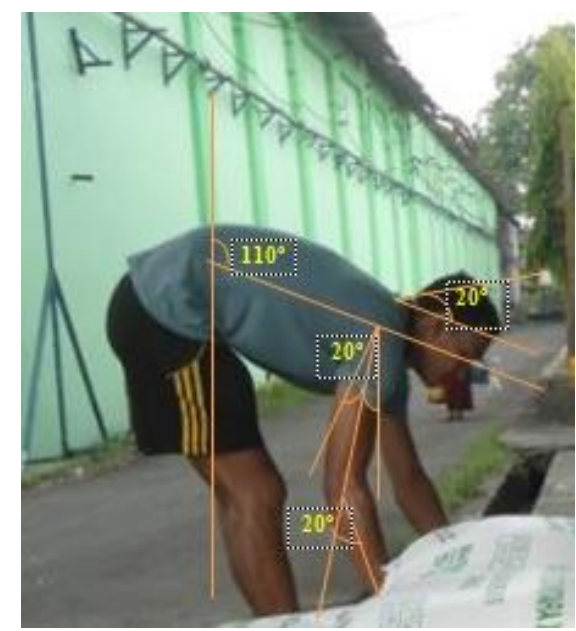

Gambar 1 Proses pengangkatan karung gula

Tabel 2 Nilai skor level aktivitas

\begin{tabular}{lccl}
\hline \multicolumn{1}{c}{ Aktivitas } & OWAS & RULA & \multicolumn{1}{c}{ Keterangan } \\
\hline $\begin{array}{l}\text { Pengang-katan } \\
\text { karung gula }\end{array}$ & 3 & 4 & OWAS Kategori 3 : Pada sikap ini berpotensi \\
& & menyebabkan ketegangan bagi ystem \\
& & musculoskeletal, sehingga perlu perbaikan \\
& & segera mungkin \\
& & RULA Kategori 4 : Kondisi tersebut sangat \\
& & dapat menyebabkan cedera Musculoskeletal \\
& & Disorders dan butuh perbaikan saat ini juga \\
\hline
\end{tabular}

b) Pekerja 2

Hasil penilaian skor level aktivitas pengangkatan karung gula pada Gambar 2 yang ditunjukkan pada Tabel 3. Hasil penilaian aktivitas menggunakan metode OWAS dan RULA diperoleh bahwa aktivitas yang dilakukan dapat menyebabkan cedera musculoskeletal sehingga diperlukan adanya perbaikan segera untuk mengurangi risiko terjadinya cedera.

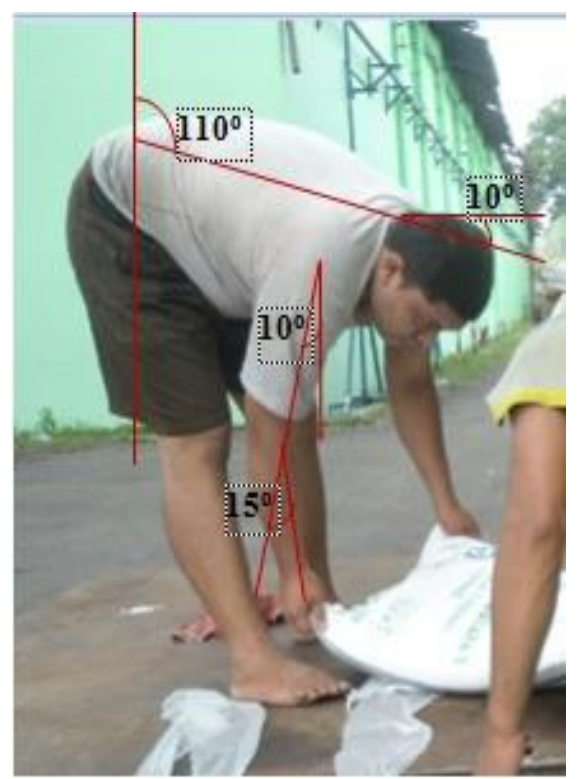

Gambar 2 Proses pengangkatan karung gula 
Tabel 3 Nilai skor level aktivitas

\begin{tabular}{lccl}
\hline \multicolumn{1}{c}{ Aktivitas } & OWAS & RULA & \multicolumn{1}{c}{ Keterangan } \\
\hline Pengang-katan & 3 & 4 & OWAS Kategori $3:$ Pada sikap ini berpotensi \\
karung gula & & & menyebabkan ketegangan bagi ystem \\
& & musculoskeletal, sehingga perlu perbaikan segera \\
& mungkin \\
& RULA Kategori $4:$ Kondisi tersebut sangat dapat \\
& menyebabkan cedera Musculoskeletal Disorders dan \\
& & membutuhkan perbaikan segera (saat ini juga) \\
\hline & &
\end{tabular}

c) Pekerja 3

Hasil penilaian skor level aktivitas pengangkatan karung gula pada Gambar 3 yang ditunjukkan pada Tabel 4.

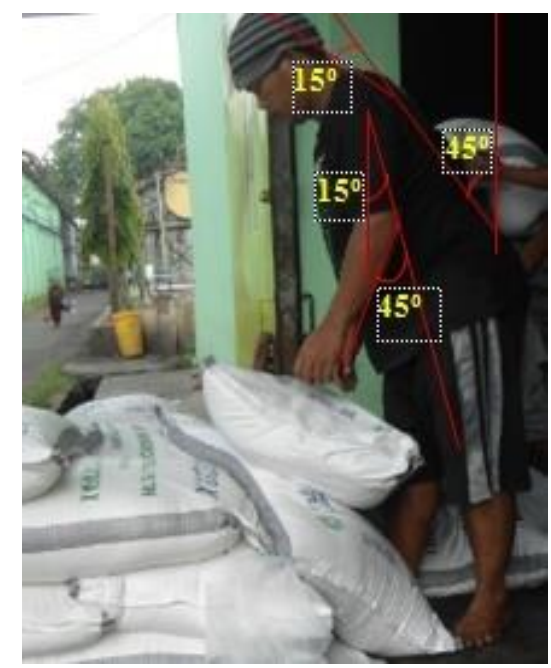

Gambar 3 Proses pengangkatan karung gula

Tabel 4 Nilai skor level aktivitas

\begin{tabular}{lccl}
\hline Aktivitas & OWAS & RULA & \multicolumn{2}{c}{ Keterangan } \\
\hline Pengang-katan & 3 & 4 & OWAS Kategori $3:$ Pada sikap ini berpotensi \\
karung gula & & menyebabkan ketegangan bagi sistem \\
& & musculoskeletal, sehingga perlu perbaikan segera \\
& mungkin & RULA Kategori $4:$ Kondisi tersebut sangat dapat \\
& menyebabkan cedera MSDs perlu perbaikan saat \\
& ini juga \\
\hline
\end{tabular}

Hasil penilaian aktivitas menggunakan metode OWAS dan RULA tersebut diperoleh bahwa aktivitas yang dilakukan dapat menyebabkan cedera musculoskeletal sehingga diperlukan adanya perbaikan segera untuk mengurangi risiko terjadinya cedera.

\subsection{Pemindahan Karung Gula}

Pada aktivitas ini, pekerja memindahkan karung gula yang berada di lori ke tempat yang telah disediakan untuk kemudian gula tersebut disusun pada gudang 
penyimpanan. Postur tubuh pekerja saat proses pemindahan karung gula dapat dilihat pada Gambar 4, Gambar 5 dan Gambar 6.

a) Pekerja 1

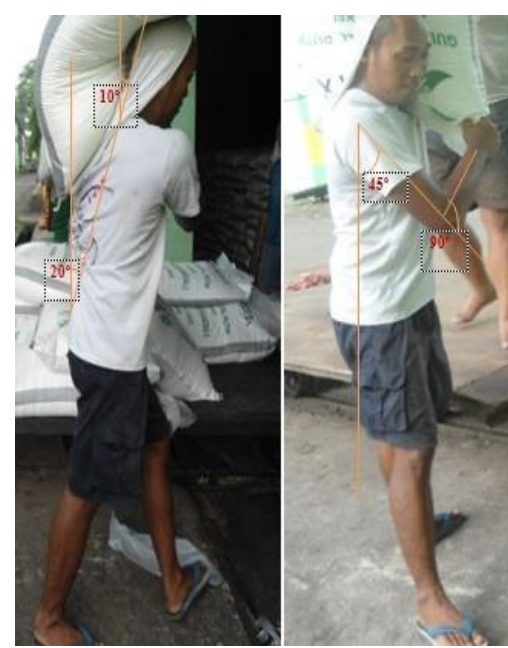

Gambar 4 Proses pemindahan karung gula

Hasil penilaian skor level aktivitas pemindahan karung gula pada Gambar 4 yang ditunjukkan pada Tabel 5.

Tabel 5 Nilai skor level aktivitas

\begin{tabular}{lccl}
\hline \multicolumn{1}{c}{ Aktivitas } & OWAS & RULA & \multicolumn{1}{c}{ Keterangan } \\
\hline Pemindahan & 4 & 4 & OWAS Kategori 4 : pada sikap tersebut \\
karung gula & & & dapat menimbulkan cedera Musculosceletal \\
& & & Disorders, dan perlu perbaikan segera. \\
& & RULA Kategori 4 : Kondisi tersebut sangat \\
& & dapat menyebabkan cedera Musculoskeleta \\
& & Disorders perlu perbaikan saat ini juga \\
\hline
\end{tabular}

Hasil penilaian aktivitas menggunakan kedua metode OWAS dan RULA diperoleh bahwa aktivitas yang dilakukan dapat menyebabkan cedera musculoskeletal sehingga diperlukan adanya perbaikan segera untuk mengurangi risiko terjadinya cedera.

b) Pekerja 2

Hasil penilaian skor level aktivitas pemindahan karung gula pada Gambar 5 yang ditunjukkan pada Tabel 6 .

Tabel 6 Nilai skor level aktivitas

\begin{tabular}{lcclc}
\hline \multicolumn{1}{c}{ Aktivitas } & OWAS & RULA & \multicolumn{3}{c}{ Keterangan } \\
\hline Pemindahan & 1 & 4 & OWAS Kategori 1 sikap ini tidak \\
karung gula & & & menyebabkan risiko cedera musculoskeletal \\
& & RULA Kategori 4 : Kondisi tersebut sangat \\
& dapat menyebabkan cedera Musculoskeletal \\
& Disorders dan membutuhkan perbaikan segera \\
(saat ini juga)
\end{tabular}




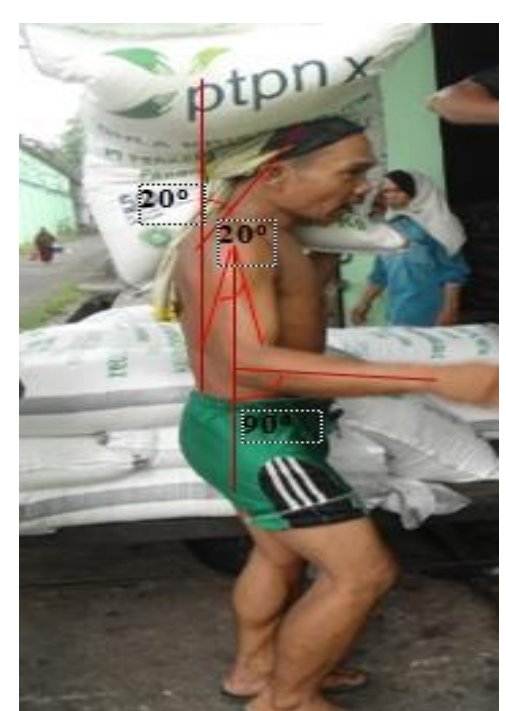

\section{Gambar 5 Proses pemindahan karung gula}

Hasil penilaian aktivitas menggunakan metode RULA tersebut diperoleh bahwa aktivitas yang dilakukan dapat menyebabkan cedera musculoskeletal sehingga diperlukan adanya perbaikan segera untuk mengurangi risiko terjadinya cedera. Namun pada metode OWAS postur tubuh tersebut tidak menyebabkan cedera, karena metode ini mengabaikan beban statis yang dialami pekerja padahal adanya beban statis tersebut sangat besar risiko menyebabkan cedera musculoskeletal.

c) Pekerja 3

Hasil penilaian skor level aktivitas pemindahan karung gula pada Gambar 6 yang ditunjukkan pada Tabel 7.

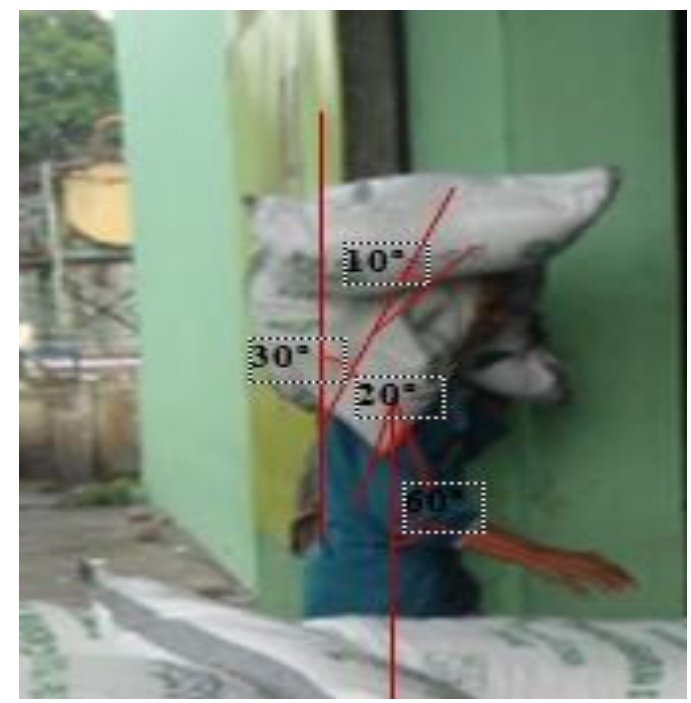

Gambar 6 Proses pemindahan karung gula

Hasil penilaian aktivitas menggunakan metode RULA tersebut diperoleh bahwa aktivitas yang dilakukan dapat menyebabkan cedera musculoskeletal sehingga diperlukan adanya perbaikan segera untuk mengurangi risiko terjadinya cedera. Namun pada metode OWAS postur tubuh tersebut tidak menyebabkan cedera, karena 
metode ini mengabaikan beban statis yang dialami pekerja padahal adanya beban statis tersebut sangat besar risiko menyebabkan cedera musculoskeletal.

Tabel 7 Nilai skor level aktivitas

\begin{tabular}{lcclc}
\hline \multicolumn{1}{c}{ Aktivitas } & OWAS & RULA & \multicolumn{2}{c}{ Keterangan } \\
\hline Pemindah-an & 1 & 4 & OWAS Kategori 1 : sikap ini tidak \\
karung gula & & & menyebabkan risiko cedera musculoskeletal \\
& & RULA Kategori 4 : Kondisi tersebut sangat \\
& & dapat menyebabkan cedera Musculoskeletal \\
& & Disorders dan membutuhkan perbaikan \\
& segera (saat ini juga)
\end{tabular}

\subsection{Peletakkan Karung Gula}

Pada aktivitas ini, pekerja meletakkan karung gula di tempat yang telah disediakan yang kemudian akan dilakukan penyusunan karung-karung gula tersebut. Gambar postur tubuh pekerja saat proses peletakan karung gula dapat dilihat pada Gambar 7, dan Gambar 8.

a) Pekerja 1

Hasil penilaian skor level aktivitas peletakan karung gula pada Gambar 7 yang ditunjukkan pada Tabel 8. Hasil penilaian aktivitas menggunakan kedua metode tersebut diperoleh bahwa aktivitas yang dilakukan dapat menyebabkan cedera musculoskeletal sehingga diperlukan adanya perbaikan segera untuk mengurangi risiko terjadinya cedera.

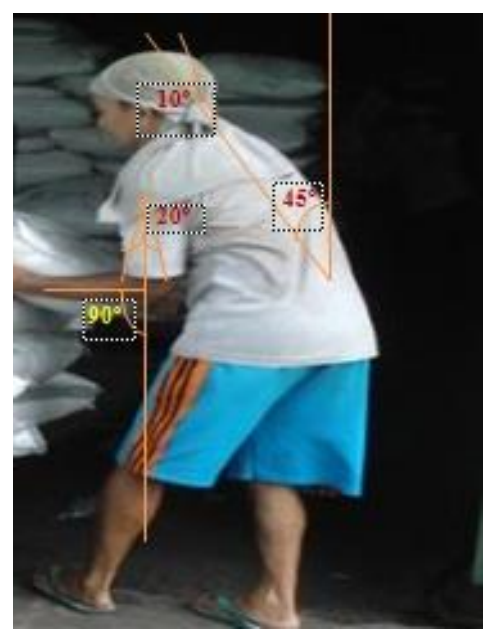

Gambar 7 Proses peletakkan karung gula

Tabel 8 Nilai skor level aktivitas

\begin{tabular}{|c|c|c|c|}
\hline Aktivitas & OWAS & RULA & Keterangan \\
\hline $\begin{array}{l}\text { Peletak-kan } \\
\text { karung gula }\end{array}$ & 3 & 4 & $\begin{array}{l}\text { OWAS Kategori } 3: \text { Pada sikap ini berpotensi } \\
\text { menyebabkan ketegangan bagi ystem musculoskeletal, } \\
\text { sehingga perlu perbaikan segera mungkin } \\
\text { RULA Kategori } 4 \text { : Kondisi tersebut sangat dapat } \\
\text { menyebabkan cedera Musculoskeletal Disorders dan } \\
\text { membutuhkan perbaikan segera (saat ini juga) }\end{array}$ \\
\hline
\end{tabular}

b) Pekerja 2 
Hasil penilaian skor level aktivitas peletakkan karung gula pada Gambar 8 yang ditunjukkan pada Tabel 9.

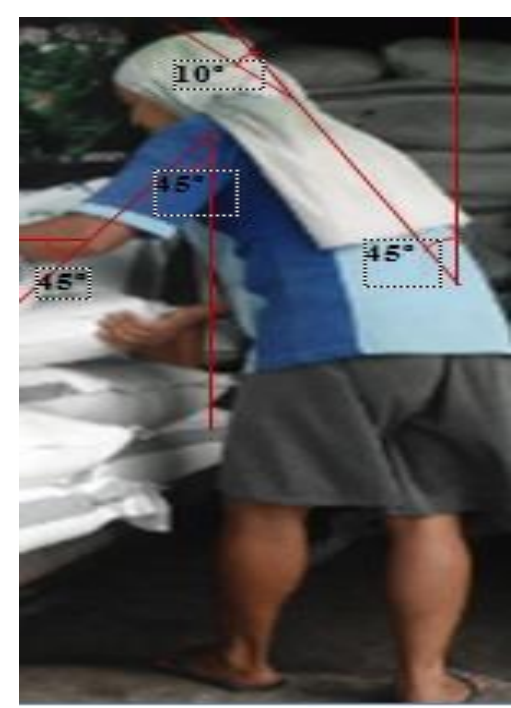

Gambar 8 Proses peletakkan karung gula

Tabel 9 Nilai Skor Level Aktivitas

\begin{tabular}{cccl}
\hline Aktivitas & OWAS & RULA & \multicolumn{1}{c}{ Keterangan } \\
\hline Peletak-kan & 3 & 4 & OWAS Kategori $3:$ Pada sikap ini berpotensi \\
karung gula & & & menyebabkan ketegangan bagi ystem \\
& musculoskeletal, sehingga perlu perbaikan \\
& segera mungkin & RULA Kategori $4:$ Kondisi tersebut sangat \\
& & dapat menyebabkan cedera Musculoskeletal \\
& Disorders dan membutuhkan perbaikan segera \\
& (saat ini juga) \\
\hline
\end{tabular}

Hasil penilaian aktivitas menggunakan metode OWAS dan RULA diperoleh bahwa aktivitas yang dilakukan dapat menyebabkan cedera musculoskeletal sehingga diperlukan adanya perbaikan segera untuk mengurangi risiko terjadinya cedera.

Hasil pengodingan level risiko dari postur tubuh dengan menggunakan metode OWAS dan RULA, dinyatakan bahwa postur tubuh pekerja selama ini yang dapat menyebabkan cedera MSDs bagi pekerja itu sendiri. Oleh karena itu, merekomendasikan sebuah alat bantu yang dapat mengurangi beban pekerja dan juga diharapkan mampu menurunkan risiko musculoskeletal bagi pekerja. Alat bantu yang direkomendasikan adalah hand truck dua roda dengan ditambahkan roda penyangga pada bagian belakang guna mengurangi beban statis yang dialami oleh tangan pekerja, dan juga dapat mencegah hand truck tersebut jatuh saat digunakan mengangkut beban berat. hand truck dua roda dapat dilihat pada Gambar 9. Data antropometri yang digunakan dalam merancang alat bantu hand truck dua roda ditunjukkan pada Tabel 10 .

Tabel 10 Data antropometri pekerja 


\begin{tabular}{clccccc}
\hline No & \multicolumn{1}{c}{ Data yang diukur } & Rata-rata & SD & P 95 & P 50 & P 5 \\
\hline $\mathbf{1}$ & Lebar bahu (lb) & 38,86 & 2,23 & 42,53 & 38,86 & 35,19 \\
$\mathbf{2}$ & Tinggi siku berdiri (tsb) & 110,15 & 5,67 & 119,48 & 110,15 & 100,82 \\
$\mathbf{3}$ & Diameter lingkar genggam (dlg) & 3,50 & 0,51 & 4,33 & 3,50 & 2,67 \\
$\mathbf{4}$ & Lebar jari (lj) & 7,63 & 0,60 & 8,61 & 7,63 & 6,65 \\
\hline
\end{tabular}

Tabel 11 Penentuan dimensi alat bantu

\begin{tabular}{cllcc}
\hline No & \multicolumn{1}{c}{ Spesifikasi } & Dimensi Tubuh & Persentil & Ukuran \\
\hline $\mathbf{1}$ & $\begin{array}{l}\text { Tinggi pegangan hand } \\
\text { truck saaat berdiri }\end{array}$ & Tinggi siku berdiri & $5 \%$ & $105,16 \mathrm{~cm}$ \\
$\mathbf{2}$ & $\begin{array}{l}\text { Lebar pegangan hand } \\
\text { truck }\end{array}$ & Lebar bahu & $95 \%$ & $42,53 \mathrm{~cm}$ \\
$\mathbf{3}$ & $\begin{array}{l}\text { Panjang pegangan hand } \\
\text { truck }\end{array}$ & Lebar jari-jari & $95 \%$ & $7 \mathrm{~cm}+($ allowance $) 8$ \\
$\mathbf{c m}=15 \mathrm{~cm}$ \\
$\mathbf{4}$ & $\begin{array}{l}\text { Diameter genggam } \\
\text { hand truck }\end{array}$ & $\begin{array}{l}\text { Diameter lingkar } \\
\text { genggam }\end{array}$ & $95 \%$ & $43 \mathrm{~cm}$ \\
$\mathbf{5}$ & $\begin{array}{l}\text { Panjang dan lebar plat } \\
\text { landasan }\end{array}$ & & & $42,53 \mathrm{~cm} \mathrm{x} 40 \mathrm{~cm}$ \\
\hline
\end{tabular}

Penentuan dimensi hand truck dua roda yang dipakai ditunjukkan pada Tabel 11. Penggunaan persentil $5 \%$ untuk menentukan tinggi pegangan hand truck saat berdiri dimaksudkan agar pekerja yang memiliki tubuh tinggi tetap nyaman memakai hand truck tersebut. Sedangkan penggunaan persentil $95 \%$ agar pekerja yang memiliki tubuh besar maupun kecil dapat menggunakan hand truck tersebut dengan nyaman.

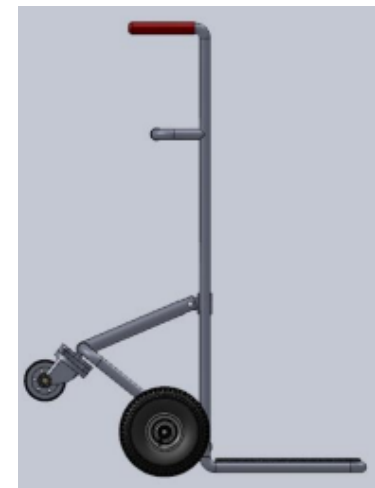

Gambar 9 Hand truck dua roda dengan roda tambahan

\section{Simpulan}

Postur kerja yang dilakukan oleh pekerja selama proses pemindahan karung gula saat ini dapat menyebabkan risiko terjadinya cedera yang tidak aman untuk keselamatan pekerja, sehingga perlu adanya perbaikan yang harus dilakukan oleh perusahaan. Hasil dari penelitian ini didapatkan usulan perancangan alat bantu kerja guna mengurangi risiko terjadinya musculoskeletal disorder bagi para pekerja material handling.

\section{Referensi}


[1] E. Nurmianto, Ergonomi, Konsep Dasar dan Aplikasinya: Jakarta:Guna Widya, 1996.

[2] R. S. Bridger, Introduction to Ergonomics: McGraw-Hill, 1995.

[3] W. Susihono, Perbaikan Metode Kerja Berdasarkan Rapid Upper Limb Assesment (RULA) Pada Perusahaan Konstruksi Dan Fabrikasi, 2009.

[4] A. R. Pamula, "Analisis Postur Kerja Pada Aktivitas Manual Material Handling Dengan Menggunakan Metode Penilian Ovako Work Analisis System (OWAS) Pada Pekerja Unit di PT. X Wilayah Semarang," 2012.

[5] B. Triyanto, Analisis Postur Kerja Menggunakan Metode Rula Dan Perancangan Ulang Stasiun Kerja Finishing Batik (Studi Kasus Pada UKM Pembuatan Batik Printing di Desa Pilang, Masaran, Sragen), 2012.

[6] M. Mattila, W. Karwowski, and M. Vilkki, "Analysis of working postures in hammering tasks on building construction sites using the computerized OWAS method," Applied ergonomics, vol. 24, pp. 405-412, 1993.

[7] N. Sari, "Perbaikan Postur Kerja Menurunkan Keluhan Musculoskeletal dan Waktu Proses Pemahatan di Java Art Stone Yogyakarta," UAJY, 2014.

[8] J. Suwanto, P. Tarwaka, and K. E. Werdani, "Hubungan Antara Risiko Postur Kerja Dengan Risiko Keluhan Musculoskeletal Pada Pekerja Bagian Pemotongan Besi Di Sentra Industri Pande Besi Padas Klaten," Universitas Muhammadiyah Surakarta, 2016.

[9] N. Dzikrillah and E. N. S. Yuliani, "Analisis Postur Kerja Menggunakan Metode Rapid Upper Limb Assessment (Rula) Studi Kasus PT TJ Forge Indonesia," Jurnal Ilmiah Teknik Industri, vol. 3, 2017.

[10] W. Susihono and E. Rubiati, "Perbaikan Metode Kerja Berdasar Rapid Upper Limb Assessment (RULA) pada Perusahaan Konstruksi dan Fabrikasi," Spektrum Industri, vol. 11, 2013.

[11] J. Priyono, Analisis Postur Kerja Dan Redesign Peralatan Kerja Menggunakan Metode Quick Exposure Check (QEC) Pada Operator Kerajinan Pencetakan Gerabah ( Studi Kasus: Home Industry Bapak Sutrisno, Wedhi, Bayat, Klaten), 2014.

[12] O. Karhu, R. Härkönen, P. Sorvali, and P. Vepsäläinen, "Observing working postures in industry: Examples of OWAS application," Applied Ergonomics, vol. 12, pp. 13-17, 1981.

[13] L. McAtamney and E. N. Corlett, "RULA: a survey method for the investigation of work-related upper limb disorders," Applied ergonomics, vol. 24, pp. 91-99, 1993.

[14] S. Wignjosoebroto, "Ergonomi, Studi Gerak dan Waktu," Edisi pertama. Jakatrta: Penerbit PT. Guna Widya, 1995. 